Trakya Eğitim Dergisi

Cilt 10, Sayı 2

May1s 2020, 330-346

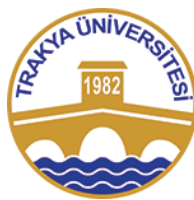

ISSN: 2630-6301

Doi: $10.24315 /$ tred.522213
Trakya Journal of Education

Volume 10, Issue 2

May 2020, .330-346

Yayına Kabul Tarihi:03.04.2020

\title{
Fen Bilgisi Öğretmen Adaylarının Aynalarda Görüntü Konusuna İlişkin Kavramsal Anlamaları ve Zihinsel Modelleri ${ }^{1}$
}

\section{Conceptual Understanding and Mental Models of Science Teacher Candidates about Image Concept in Mirrors}

\section{Ümmü Gülsüm DURUKAN² ${ }^{2}$ Günay PALIÇ ŞADOĞLU ${ }^{3}$}

ÖZ: Bu çalışmanın amacı, fen bilgisi öğretmen adaylarının aynalarda görüntü konusuna dair kavramsal anlamalarını ve zihinsel modellerini tespit etmektir. Çalışmada, özel durum çalışma deseni benimsenmiştir. Çalışmanın katılımcılarını, Doğu Karadeniz bölgesindeki bir üniversitede eğitim fakültesinin 2 . sınıfında öğrenim gören ve Genel Fizik III Laboratuvarı dersini alan gönüllü 29 fen bilgisi öğretmen adayı oluşturmaktadır. Çalışmanın verileri, araştırmacılar tarafından hazırlanmış üç açık uçlu sorudan oluşan bir form aracılığıyla toplanmıştır. Veri toplama aracında yer alan sorular, görüntü kavramının tanımlanmasına, görüntü oluşumunun açıklamasına ve farklı ayna türlerinde örnek görüntü çizimi yapılmasına yöneliktir. Elde edilen veriler içerik analizi ile analiz edilmiş, frekans ve yüzde değerleri ile birlikte tablolar halinde sunulmuştur. Çalışmada, öğretmen adaylarının görüntü kavramını görüntü oluşumu ile, aynalar/yansıtıcı yüzeyi olan cisimler kullanılarak oluşturulan şekil ile, yansıma olayı ile ve gölge oluşumu ile açıkladıkları tespit edilmiştir. Öğretmen adaylarının görüntü oluşumu için, en az iki ışın kullanılarak, yansıma kanunlarının ve cismin simetrik yansımasının alınması ile çizim yapıldığını belirttikleri ve örnek çizimler yaptıkları görülmüştür. Ayrıca adayların farklı ayna türlerinde örnek görüntü çizimi yapmakta zorlandıkları ve görüntü çizimini doğru yapamadıkları için oluşan görüntünün özelliklerini belirtemedikleri tespit edilmiştir. Çalışmada, ulaşılan sonuçlara dikkate alınarak görüntü kavramı, görüntü oluşumu ve aynalarda görüntü konularının öğretimine yönelik bazı önerilerde bulunulmuştur.

Anahtar sözcükler: Görüntü, kavramsal anlama, zihinsel model, fen bilgisi öğretmen adayı

\begin{abstract}
The aim of this study is to determine the conceptual understanding and mental models of science teacher candidates on the concept of image, image formation and image in mirrors. The study is carried out case study method. The participants of the study consist of 29 science teacher candidates who studying in the 2nd grade of the faculty of education in a university in the Eastern Black Sea region and taking the General Physics III Laboratory course. The data of the study were collected through a form consisting of three open-ended questions prepared by the researchers. The questions in the data collection tool are aimed at defining the concept of the image, explaining the image formation and drawing images for sample situations in different mirror types. The obtained data were analysed by content analysis and presented as tables with frequency and percentage values. In the study, it was determined that the science teacher candidates explained the concept of image by the image formation, with the shape created by using the mirrors / reflective surface objects, reflection and shadow formation. It was seen that the science teacher candidates did the image formation by using at least two beams, drawing the symmetrical reflection the object and the reflection laws and also, they made the sample drawings. In addition, it was determined that the science teacher candidates had difficulty in making sample image in different mirror types and they could not determine the characteristics of the image because they could not make the image drawing correctly. In the study, some suggestions have been made regarding image concept, image formation and teaching of image subjects in mirrors by taking into consideration the results reached.
\end{abstract}

Keywords: Image, conceptual understanding, mental model, science teacher candidate

\section{Bu makaleye attf vermek için:}

Durukan, Ü. G. ve Paliç-Şadoğlu, G. (2020). Fen bilgisi öğretmen adaylarının aynalarda görüntü konusuna ilişkin kavramsal anlamaları ve zihinsel modelleri. Trakya Eğitim Dergisi, 10(2), 330-346

Cite this article as:

Durukan, U. G. \& Palic-Sadoglu, G. (2020). Conceptual understanding and mental models of science teacher candidates about image concept in mirrors. Trakya Journal of Education, 10(2), 330-346

\footnotetext{
${ }^{1} \mathrm{Bu}$ çalışmanın bir kısım verileri, 10-13 Ekim 2018 tarihleri arasında düzenlenen 3. Uluslararası Felsefe, Eğitim, Sanat ve Bilim Tarihi Sempozyumu'nda sözlü olarak sunulmuștur.

${ }^{2}$ Arş. Gör. Dr., Giresun Üniversitesi, Eğitim Fakültesi, Matematik ve Fen Bilimleri Eğitimi Bölümü, u.g.durukan@gmail.com, ORCID: 0000-0002-9279-2812

${ }^{3}$ Dr., Karadeniz Teknik Üniversitesi, e-posta: gunaypalic@ hotmail.com. ORCID ID: 0000-0003-0599-5329
} 


\section{EXTENDED ABSTRACT}

\section{Introduction}

One of the basic concepts in optical subjects is the concept of image. In the literature, different studies have been carried out about image and image formation in different optical instruments. In these studies, it is stated that the students have difficulty in defining the concept of image, drawing images in different types of mirrors, and understanding the properties of the image, explain the image formation associating with the seeing or using plane mirror. In addition, the problems, which are mentioned in the studies about the image concept, have also been experienced after teaching sequence of the subject. In addition to identifying the accuracy or inaccuracy of the information that the students have about the image in the mirrors, it is considered important to determine their mental models in order to discuss how they internalized this information. Although mental models are a representation of knowledge, they are mental structures that are individual, incomplete, improvable and modifiable (dynamic), sometimes non-scientific, and reflect the beliefs of people on the representative system (Vosniadou \& Brewer, 1992; Buckley \& Boulter, 2000; Franco \& Colinvaux, 2000; Harrison \& Treagust, 2000; Kurnaz \& Değermenci, 2012). Identifying the mental models that students have and the characteristics of the mental models on the subject or the concept can be considered as an indicator of what they learn (Ünal \& Ergin, 2006; İyibil \& Sağlam-Arslan, 2010). Besides, the mental models can be used as a measurement tool to determine whether students understand the subject (Greca \& Moreira, 2002; Örnek, 2008). At this point, it is thought that the study about examining the mental models of the subject in the mirrors in order to reveal the structuring of the participants' knowledge about the subject will be required. In this context, the aim of this study was to determine; the conceptual understanding and mental models of the science teacher candidates about the image in the mirrors.

\section{Method}

The study was carried out by case study method. The participants of the study were consisted of 29 science teacher students who studying in the 2 nd grade of the faculty of education in a university in the Eastern Black Sea region and taking the General Physics III Laboratory course. The data of the study were collected through a form consisting of three open-ended questions prepared by the researchers. The questions in the data collection tool are aimed at defining the concept of image, explaining the image formation and drawing sample images in different types of mirrors. The data were analyzed by content analysis. As a result of analysis; the explanations are grouped under three categories: the correct explanation, the partially correct explanation and the wrong explanation. The unanswered questions are placed in the category of 'no explanation'. The results are presented as tables with frequency and percentage values. The mental model analysis was carried out in two stages: In the first stage, the answers of the science teacher candidates to the questions about the image in the mirrors and the candidates' conceptual understandings about the subject were evaluated individually on the basis of questions. In the second stage, based on this individual assessment, the categories of the candidates' conceptual understandings about the subject were evaluated and grouped according to the common points they showed. As a result of this process, the mental model types of the candidates were determined.

\section{Result and Discussion}

In this study, which aims to determine the conceptual understanding and mental models of science teacher candidates on the concept of image, image formation and image in mirrors, it was identified that the science teacher candidates have the lack of knowledge about the image and its characteristics. With this study, it was revealed that the science teacher candidates could not explain the image and image formation and also draw the image. It was determined that the science teacher candidates explained the concept of image with the image formation, the shape created by using with mirrors / reflective surface objects, reflection and shadow formation. It was seen that the science teacher candidates did the image formation by using at least two beams, drawing the symmetrical reflection the object and the reflection laws and also, they made the sample drawings. Some of the science teacher candidates were able to draw the image correctly. Science teacher candidates have difficulty in making sample images in different mirror types and they cannot determine the properties of the image because 
they cannot make the image drawing correctly. It was observed that the science teacher candidates made the image drawing in plane mirror more accurately than spherical mirrors. It was determined that the science teacher candidates had 7 different mental models. It is seen that $6.90 \%$ of the teacher candidates have the mental model type called TYPE1 in which they can make the right explanations to the questions in the theoretical and practical blocks. Again, a small number of candidates (10.34\%) were found to have a TYPE7 model type, which is named as primitive model (Vosniadou \& Brewer, 1992, 1994), incompatible model (İyibil, 2010) and have non-scientific content. It was determined that a significant portion of the candidates had mental model were named as TYPE4 (they made partial correct explanations to the questions in the theoretical and practical blocks) and TYPE5 (they made partial correct explanations to the questions in the theoretical block and wrong explanations to the questions in the practical block). Within the scope of the study, it is suggested that science teacher candidates should be directed to drawing of images in physics laboratories. The candidates can verify the location and properties of the image they found during the experiment by drawing.

\section{GíRiş}

Optik konuları içerisinde yer alan temel kavramlardan birisi de görüntü kavramıdır. Görüntü denildiğinde bireylerin aklına görme olayı, fotoğraf, manzara, televizyon, gölge ve aydınlanma gibi (Çiftçi \& Çökelez, 2012) farklı anlamlar taşıyan kelimeler gelebilmektedir. Bireylerin günlük hayatlarında kullandıkları bu farklı anlamlandırmalar, sınıf ortamına da taşınabilmekte, öğrenme sürecinde kavramlarını yapılandırırken bu yapının bir parçası olabilmekte ve bireylerin alternatif kavramlara sahip olmalarına sebep olabilmektedir. Bu noktada, bireylerin ön öğrenmelerinin ve önceki deneyimlerinin önemli olduğu, bu deneyimlerini yanlış yorumladıkları için kavramı veya konuyu anlamakta zorluk çektikleri söylenebilir (Chi, 1992). Görüntü kavramını inceleyen çalışmalardan Goldberg ve McDermott (1987) ile Çiftçi ve Çökelez (2012) çalışmalarında özellikle görüntünün günlük hayatta çok anlamlı olarak kullanılmasının alternatif kavramlar ortaya çıkarabileceğini ifade etmiştir.

Literatürde görüntü ve farklı optik aletlerde görüntü oluşumu ile ilgili farklı çalışmalar yürütülmüştür. Bu çalışmalardan, Kocakülah (2006) çalışmasında farklı öğrenim seviyelerindeki katılımcılarının görüntü oluşumuna dair düşünce biçimlerini araştırmıştır. Bu çalışma sonucunda farklı öğrenim seviyelerinde olsalar da katılımcıların ortak alternatif kavramlara sahip oldukları ve sanal / gerçek görüntünün ayırt edilmesi ile görüntü oluşumuna ilişkin çizilen 1şın diyagramlarında benzer alternatif kavramlar sergiledikleri belirlenmiştir. Ahçı (2012) çalışmasında üniversite öğrencilerinin 1şık ve optik konuları ile ilgili kavramsal anlamalarını belirlemeyi amaçlamıştır. Öğrencilerin optik konuları arasından düzlem aynada görüntü oluşumu ile ilgili düzlem aynanın önünde duran bir cismin görüntüsünün düzlem aynanın önünde veya yüzeyinde oluştuğu gibi alternatif kavramlara sahip olduklarını tespit etmiştir. Goldberg ve McDermott (1987), öğrencilerin ince kenarlı mercek ve çukur aynada oluşan görüntüleri nasıl algıladıklarını belirlemek amacıyla yapmış olduğu çalışmasında, öğrencilerin optik sistemin bileşenleri arasındaki ilişki kuramadıkları, 1şık 1şını kavramı ve 1şık diyagramlarını açıklamada yetersiz oldukları sonucuna ulaşmıştır. Galili ve Hazan (2000) yaptığı çalışmada öğrencilerin 1şı̆̆ın yayılması, görme olayı ve gölge ile ilgili alternatif kavramlara sahip oldukları belirlemiştir. Kara, Kanlı ve Yağbasan (2003) yaptıkları çalışmada öğrencilerin 1şık ve optik konularında anlamakta güçlük çektikleri kavramları araştırmış, öğrencilerin çukur ve tümsek aynadaki bilgilerini tam olarak yorumlayamadıklarını ortaya çıkarmıştır. Şen (2003) ilköğretim öğrencilerinin görüntünün aynanın üzerinde bulunduğu; düzlem bir aynanın sağ-sol değişimi yaptığı şeklinde alternatif kavramlara sahip oldukları sonucuna ulaşmıştır. Anıl ve Küçüközer (2010) çalışmasında ortaöğretim dokuzuncu sınıf öğrencilerinin düzlem ayna konusuna ilişkin sahip oldukları ön bilgilerini ve alternatif kavramlarını incelemiş ve öğrencilerin düzlem ayna görüntü oluşumu ile ilgili birçok yanlış bilgiye sahip olduğunu ifade etmiştir. Durukan ve Aygün (2014) fen bilgisi öğretmen adayları ile yürüttüğü çalışmasında, adayların görüntü çizimi yaparken zorlandıklarını ve görüntünün özelliklerini tespit edemediklerini göstermiştir. Çökelez ve Çiftçi-Yaşar (2015) altıncı sınıf öğrencilerinin görüntü kavramı ile ilgili kavramsal öğrenmelerini belirlemeyi amaçlayan çalışmasında görme kavramının yapısında var olan sorunların, görüntü kavramının kavramsal öğrenimini etkilediğini de ortaya koymuştur. Özetle literatürde, öğrencilerin görüntü kavramını tanımlamakta zorlandıkları, görüntü 
oluşumunu görme olayı ile ilişkilendirerek ya da düzlem ayna kullanarak açıkladıkları, farklı tür aynalarda görüntü çizimi yapmakta ve oluşan görüntünün özelliklerini kavramakta zorlandıkları belirtilmektedir. Bunun yanı sıra, çalışmalarda görüntü kavramına ilişkin belirtilen bu problemlerin, konunun öğretiminden sonra da yaşandığı tespit edilmiştir (Kocakülah, 2006; Anıl \& Küçüközer, 2010).

Öğrencilerin aynalarda görüntü konusunda sahip oldukları bilgilerin doğruluğunu ya da yanlışlığını tespit etmenin yanında, konu ile ilgili tespit edilen bu bilgilerini nasıl içselleştirdiklerini tartışabilmek açısından, onların zihinsel modellerinin belirlenmesinin önemli olduğu düşünülmektedir. Zihinsel modeller, insanların düşüncelerinde var olan gerçek durumların içsel sunumlarıdır (Franco \& Colinvaux, 2000). Zihinsel modeller, bilginin bir temsili olmakla birlikte bireylere özgü, tamamlanmamış, geliştirilebilir ve değiştirilebilir (dinamik), kimi zaman bilimsel olmayan ve insanların temsili sistem üzerine inanışlarını yansıtan zihinsel yapılardır (Vosniadou \& Brewer, 1992; Buckley \& Boulter, 2000; Franco \& Colinvaux, 2000; Harrison \& Treagust, 2000; Kurnaz \& Değermenci, 2012). Zihinsel model, yeni bilgiler kazanıldıkça birey tarafindan geliştirilir ve birey için modelin fonksiyonel olması sağlanır (Norman, 1983; Greca \& Moreira, 2000). Bireylerin sahip oldukları zihinsel modellerin ortaya çıkarılması, konuya ya da kavrama dair modellerin özelliklerinin tespit edilmesi, öğrencilerin neyi nasıl öğrendiğinin bir göstergesi olarak düşünülebilir (Ünal \& Ergin, 2006; İyibil \& SağlamArslan, 2010). Bu noktada, zihinsel modeller öğrencilerin konuyu anlayıp anlamadıklarını belirlemek amacıyla bir ölçme aracı olarak kullanılabilir (Greca \& Moreira, 2002; Örnek, 2008). Nitekim literatürde farklı konu ve kavramlar için yürütülen zihinsel model çalışmaları bulunmaktadır: Örneğin, Dünya (Vosniadou \& Brewer, 1992; İyibil, 2010), 1şık (Hubber, 2006), gölge (Ünal-Çoban \& KayaŞengören, 2009), ses (Hrepic, 2002).

Görüntü kavramı ve aynalarda görüntü konusu ile ilgili katılımcıların kavramsal anlamalarına odaklanan birçok çalışma literatürde yer almaktadır. Literatürde yer alan bu çalışmalarda, öğrencilerin görüntü kavramını tam anlamıyla açıklayamadıkları, görüntü oluşumunu görme olayı ile açıklamaya çalıştıkları, çeşitli aynalarda görüntü çizimi yapmakta ve oluşan görüntünün özelliklerini kavramakta zorlandıkları sonuçlarına ulaşılmıştır (Goldberg \& McDermott, 1987; Galili \& Hazan, 2000; Kara, Kanlı \& Yağbasan, 2003; Şen, 2003; Anıl \& Küçüközer, 2010; Çökelez \& Çiftçi-Yaşar, 2015). Bireylerin ön öğrenmelerinin veya önceki deneyimlerinin önemli olduğu ve sahip oldukları ön bilgi veya deneyimlerini yanlış yorumladıkları için ilgili kavramı veya konuyu anlamakta zorluk çektikleri bilinmektedir. Bu noktada, öğrencilerin kavram veya konu ile ilgili tespit edilen ön bilgi ve deneyimlerini nasıl içselleştirdiklerinin belirlenebilmesi ve tartışılabilmesi için doğası gereği kullanışlı bir araç olduğu düşünülen zihinsel modellerinin irdelenmesi önem kazanmaktadır. Bu çalışmada öğrencilerin farklı ayna türlerinde görüntü konusunda sahip oldukları bilgilerinin doğruluğunun ya da yanlışlığının tespit edilmesinin yanında, onların konu ile ilgili zihinsel modelleri de incelenmektedir. $\mathrm{Bu}$ bağlamda yapılan bu çalışmanın amacı, fen bilgisi öğretmen adaylarının aynalarda görüntü konusundaki kavramsal anlamalarını ve zihinsel modellerini tespit etmektir.

\section{YÖNTEM}

\subsection{Araştırmanın Modeli}

$\mathrm{Bu}$ çalışma, özel durum yöntemi ile yürütülmüştür. Özel durum yöntemi, araştırılan problemin kısa sürede çalışılmasına imkan sağlayan (Çepni, 2010), güncel bir olguyu kendi yaşam çerçevesi ve içeriği içinde çalışan (Yin, 2003) ve derinlemesine çalışma ve karşılaştırma yapmak için verinin özel durumlara göre düzenlenmesini içeren (Patton, 1990) bir araştırma yöntemidir. Özel durum yönteminin, öğretmen adaylarının görüntü kavramına yönelik kavramsal anlamalarını ve zihinsel modellerini tespit etmeyi amaçlayan bu çalışmanın doğasına uygun olduğu düşünülmektedir.

\section{2. Çalışma Grubu}

Çalışma grubunu, Doğu Karadeniz bölgesindeki bir üniversitenin eğitim fakültesinde ikinci sınıfta öğrenim gören ve Genel Fizik III Laboratuvarı dersini alan gönüllü 29 fen bilgisi öğretmen adayı oluşturmaktadır. 


\subsection{Veri Toplama Aracı}

Çalışmanın verileri, araştırmacılar tarafından hazırlanmış üç açık uçlu sorudan oluşan bir form aracılığıyla toplanmıştır (Ek-1). Veri toplama aracının oluşturulması sürecinde açık uçlu soruların seçilmesinin temel nedeni, bireylerin belirtilen durumlara ilişkin algılamalarını kendi ifadeleriyle belirtmelerine firsat sunmasıdır. Zihinsel modellerin temel kaynağını bireylerin algılama yeteneklerinin oluşturduğu (Johnson-Laird, 1983) düşünüldüğünde bireylerin verilen duruma ilişkin algılarına dair ifadelerinden hareketle konuya yönelik zihinsel modelleri ortaya çıkarılabilir.

Veri toplama aracında yer alan sorular, teorik sorular olarak görüntü kavramının tanımlanmasına, görüntü oluşumunun açıklamasına ve pratik sorular olarak farklı ayna türlerinde örnek görüntü çizimi yapılmasına yöneliktir. Öğretmen adayları formda yer alan soruları cevaplarken süre konusunda serbest bırakılmışlardır.

\subsection{Verilerin Analizi}

Elde edilen veriler içerik analizi ile analiz edilmiştir. Analiz sonucunda veriler; doğru açıklama, kısmen doğru açıklama ve yanlış açıklama olmak üzere üç kategori altında toplanmıştır. Yanıtsız bırakılan sorular ise açıklama yapılmadı kategorisine yerleştirilmiştir. Bulgular frekans ve yüzdelik değerleri ile birlikte tablolar halinde sunulmuştur.

Öğretmen adaylarının aynalarda görüntü konusundaki kavramsal anlamalarının analizi aşamasında; elde edilen veriler araştırmacılar tarafından bağımsız olarak analiz edilmiş ve kategorilere yerleştirilmiştir. Araştırmacılar bir araya gelerek, ayrı ayrı yapılan analizleri karşıllaştırmış ve analiz farklılıkları için araştırmacılar görüş birliğine vararak gerekli düzenlemeleri yapmıştır. Araştırmanın güvenirliği Miles ve Huberman'ın (1994) [Güvenirlik=görüş birliği/(görüş birliği+görüş ayrılığı)] formülü kullanılarak \%87 olarak belirlenmiştir.

Zihinsel model analizi iki aşamada gerçekleştirilmiştir: Birinci aşamada, fen bilgisi öğretmen adaylarının aynalarda görüntü konusundaki sorulara verdikleri yanıtlar ile adayların konuya yönelik kavramsal anlamaları soru bazında bireysel olarak değerlendirilmiştir (Ek-2). Bu bireysel değerlendirmeden yola çıkılarak, adayların konuya yönelik kavramsal anlamalarının yer aldığ kategoriler değerlendirilmiş ve gösterdikleri ortak noktalara göre gruplandırılmıştır. Bu işlemin sonucunda, adayların sahip olduğu zihinsel model türleri tespit edilmiştir (Tablo 1).

Tablo 1.

Zihinsel model belirleme tablosu ve zihinsel modellerin özellikleri

\begin{tabular}{|c|c|c|c|c|c|c|c|}
\hline \multirow[t]{2}{*}{ Model Türü } & \multicolumn{3}{|c|}{ Teorik blok } & \multicolumn{3}{|c|}{ Pratik blok } & \multirow[t]{2}{*}{ Modelin Özellikleri } \\
\hline & D & KD & Y/B & D & KD & $\mathbf{Y} / \mathbf{B}$ & \\
\hline TíP1 & $\checkmark$ & & & $\checkmark$ & & & $\begin{array}{l}\text { Konuya dair hem teorik sorulara hem de } \\
\text { pratik sorulara doğru yanıtlar } \\
\text { verebilmektedir. }\end{array}$ \\
\hline TİP2 & $\checkmark$ & & & & $\checkmark$ & & $\begin{array}{l}\text { Konuya dair teorik sorulara yanıt } \\
\text { verebilirken, pratik sorulara kısmen doğru } \\
\text { yanıtlar verebilmektedir. }\end{array}$ \\
\hline TİP3 & $\checkmark$ & & & & & $\checkmark$ & $\begin{array}{l}\text { Konuya dair teorik sorulara yanıt } \\
\text { verebilirken, pratik sorulara yanıt } \\
\text { verememektedir. }\end{array}$ \\
\hline TíP4 & & $\checkmark$ & & & $\checkmark$ & & $\begin{array}{l}\text { Konuya dair hem teorik sorulara hem de } \\
\text { pratik sorulara kısmen doğru yanıtlar } \\
\text { verebilmektedir. }\end{array}$ \\
\hline TİP5 & & $\checkmark$ & & & & $\checkmark$ & $\begin{array}{l}\text { Konuya dair teorik sorulara kısmen doğru } \\
\text { yanıt verebilirken, pratik sorulara yanıt } \\
\text { verememektedir. }\end{array}$ \\
\hline TíP6 & & & $\checkmark$ & $\checkmark$ & & & $\begin{array}{l}\text { Konuya dair teorik sorulara yanıt } \\
\text { veremezken, pratik sorulara yanıt } \\
\text { verebilmektedir. }\end{array}$ \\
\hline
\end{tabular}


Öğretmen adaylarının aynalarda görüntü konusundaki zihinsel modellerinin belirlenmesi aşamasında ise adayların konuya yönelik kavramsal anlamalarının yer aldığı kategoriler araştırmacılar tarafından bağımsız olarak değerlendirilerek ortak noktalara göre ayrı ayrı gruplandırılmıştır. Bu işlemin ardından katılımcıların kavramsal anlamalarının zihinsel model kategorilerine göre sinıflandırılması bir araştırmacı tarafindan yapıldıktan sonra diğer araştırmacı tarafından kontrol edilerek ve tekrarlanarak gerekli düzenlemeler yapılmıştır.

\section{BULGULAR}

Çalışma süresince elde edilen veriler iki başlık altında toplanmıştır: 1) Fen bilgisi öğretmen adaylarının aynalarda görüntü konusundaki kavramsal anlamaları ve 2) Fen bilgisi öğretmen adaylarının görüntü kavramına dair zihinsel modelleri.

\subsection{Fen Bilgisi Öğretmen Adaylarının Aynalarda Görüntü Konusundaki Kavramsal Anlamaları}

Fen bilgisi öğretmen adaylarının aynalardaki görüntü konusundaki kavramsal anlamalarını değerlendirmek için görüntü kavramı, görüntü oluşumu ve aynalarda görüntü ile ilgili açıklamaları değerlendirilmiştir. Öğretmen adaylarının görüntü kavramına yönelik açıklamalarının kategorilere göre dağılımı Tablo 2'de verilmektedir.

Tablo 2.

Adayların görüntü kavramına yönelik açıklamaları

\begin{tabular}{|c|c|c|c|c|}
\hline Kategori & Ö. Adayı & f & $\%$ & Alıntılar \\
\hline $\begin{array}{l}\text { Doğru } \\
\text { açılklama }\end{array}$ & $\begin{array}{l}\text { Ö1, Ö2, } \\
\text { Ö4, Ö6, } \\
\text { Ö7, Ö8, } \\
\text { Ö11, Ö12 } \\
\text { Ö14, Ö18, } \\
\text { Ö20, Ö22, } \\
\text { Ö28 }\end{array}$ & 13 & 44,83 & $\begin{array}{l}\text { "Görüntü oluşumu için ayna, cisim ve 1şına ihtiyacımız vardır. Cisim } \\
\text { üzerine en az iki 1şın gönderdiğimizde yansıyan 1şınların kesiştiği } \\
\text { noktada görüntü oluşur". Ö1 } \\
\text { "Görüntünün oluşabilmesi için bir ışık kaynağına ihtiyaç vardır. Işık } \\
\text { kaynağından da örneğin ayna, aynaya gelen ışılar yansıyacaktır. } \\
\text { Yansıyan ışılların uzantıları ya da kendileri bir yerde kesişirler ve } \\
\text { görüntü orada oluşur". Ö28 }\end{array}$ \\
\hline $\begin{array}{l}\text { Kısmen } \\
\text { doğru } \\
\text { açıklama }\end{array}$ & $\begin{array}{l}\text { Ö3, Ö9, } \\
\text { Ö10, Ö21, } \\
\text { Ö23, Ö26, } \\
\text { Ö27 }\end{array}$ & 7 & 24,14 & $\begin{array}{l}\text { “Görüntü olması için bir 1şık kaynağı ve cismi yansıtıcı aletler olması } \\
\text { gerekir”. Ö3 } \\
\text { "Tümsek ya da çukur aynanın önüne koyduğumuz cismin aynadan } \\
\text { yansımasıdır”. Ö23 } \\
\text { "Bir aynaya 1şı gönderdiğimizde aynada sanal ve gerçek olmak } \\
\text { üzere çeşitli görüntüler oluşur”. Ö26 }\end{array}$ \\
\hline $\begin{array}{l}\text { Yanlış } \\
\text { açılklama }\end{array}$ & $\begin{array}{l}\text { Ö5, Ö15, } \\
\text { Ö16, Ö17, } \\
\text { Ö24 }\end{array}$ & 5 & 17,24 & $\begin{array}{l}\text { "Işınların yansıyan cisimde oluşturduğu şekildir". Ö5 } \\
\text { "Görüntü zihnimizde canlandırabildiğimiz gerçek ya da sanal olan } \\
\text { her șeydir. Örneğin, kendi görüntüm veya araba görüntüsü... } \\
\text { Gölgeler bizim görüntümüzdür. Gölge görüntünün 1şı̆ı soğurmuş } \\
\text { halidir". Ö15 }\end{array}$ \\
\hline $\begin{array}{l}\text { Açıklama } \\
\text { yapılmadı }\end{array}$ & $\begin{array}{l}\text { Ö13, Ö19, } \\
\text { Ö25, Ö29 }\end{array}$ & 4 & 13,79 & \\
\hline
\end{tabular}

Öğretmen adaylarının görüntü kavramına yönelik açıklamaları incelendiğinde, adayların \%44,83’ünün doğru, \%24,14'ünün kısmen doğru ve \%17,24'ünün yanlış açıklama kategorisinde yer alan cevaplar verdikleri Tablo 2'de görülmektedir. Çalışmaya katılan 4 aday $(\% 13,79)$ ise görüntü kavramını açıklamamıştır. Adaylar görüntü kavramını görüntü oluşumu (Ö1, Ö4, Ö6, Ö8) ile, aynalar/yansitıc1 yüzeyi olan cisimler kullanılarak oluşturulan şekil (Ö2, Ö5, Ö7, Ö9, Ö10, Ö11, Ö12, Ö21) ile, yansıma olayı (Ö16, Ö24) ile ve gölge oluşumu (Ö15) ile açıklamıştır. 
Öğretmen adaylarının görüntü çiziminin nasıl yapılacağına yönelik açıklamalarının kategorilere göre dağılımı Tablo 3'de verilmektedir.

Tablo 3.

Adayların görüntü çiziminin nasıl yapılacağına yönelik açıklamaları

\begin{tabular}{|c|c|c|c|c|}
\hline Kategori & Ö. Adayı & f & $\%$ & Alıntılar \\
\hline $\begin{array}{l}\text { Doğru } \\
\text { açıklama }\end{array}$ & Ö1, Ö20 & 2 & 6,90 & $\begin{array}{l}\text { "Cisim üzerinden en az iki noktadan (merkez, odak, tepe noktası } \\
\text { vb) ışın gönderdiğimizde yansıyan ışınların uzantılarının kesiştiği } \\
\text { yerde görüntü oluşur”. Ö1 } \\
\text { “..aynaya en az iki ışı gönderilir. Bu ışınların yansıdıktan sonraki } \\
\text { kesiştikleri yerde görüntü oluşur. Eğer yansıyan ışınların kendisi } \\
\text { kesişiyorsa görüntü gerçek, uzantıları kesişiyorsa görüntü } \\
\text { sanaldır”. Ö20 }\end{array}$ \\
\hline $\begin{array}{l}\text { Kısmen } \\
\text { doğru } \\
\text { açılklama }\end{array}$ & $\begin{array}{l}\text { Ö2, Ö4, Ö5, } \\
\text { Ö6, Ö7, Ö8, } \\
\text { Ö11, Ö14, } \\
\text { Ö16, Ö17, } \\
\text { Ö18, Ö21 } \\
\text { Ö22, Ö23, } \\
\text { Ö25, Ö26 } \\
\text { Ö28, Ö29 }\end{array}$ & 18 & 62,07 & $\begin{array}{l}\text { "Aynaya cisimden ışıllar göndererek çizim yaparız". Ö2 } \\
\text { "Görüntü çizimi yaparken iki ışın gönderilir. Tepe noktasına; } \\
\text { normalle aynı açıyı yapacak şekilde geri yansır. Asal eksene } \\
\text { paralel; uzantısı odaktan geçecek ve normalle eşit açı yapacak } \\
\text { şekilde geri yansır". Ö6 } \\
\text { "Cisimden aynaya ışınlar gönderip yansımalarını çizeriz". Ö25 }\end{array}$ \\
\hline $\begin{array}{l}\text { Yanlış } \\
\text { açılklama }\end{array}$ & $\begin{array}{l}\text { Ö3, Ö12, } \\
\text { Ö13, Ö15 } \\
\text { Ö19, Ö24, } \\
\text { Ö27 }\end{array}$ & 7 & 24,14 & $\begin{array}{l}\text { "Cisimden farklı 1şınlar yollayıp, cisimle aynı şekilde boyut ve } \\
\text { yön olarak farklı görüntü elde ederiz". Ö12 } \\
\text { "Cisim üzerine belli noktalara 1şınlar gönderilerek, 1şınların } \\
\text { kesiştiği yerde görüntü oluşumu olur". Ö19 } \\
\text { "Görüntüden ayna uçlarına 1şı yollarız. Gelen ve yansıyan } \\
\text { 1şıların uzantılarının kesiştiği noktada görüntü oluşur". Ö24 } \\
\text { "Paralel bir 1şın gönderdiğimizde bu şıı ya odaktan ya merkezden } \\
\text { ya da merkezle odak arasından geçebilir". Ö27 }\end{array}$ \\
\hline $\begin{array}{l}\text { Açıklama } \\
\text { yapılmadı }\end{array}$ & Ö9, Ö10 & 2 & 6,90 & \\
\hline
\end{tabular}

Görüntü çiziminin nasıl yapılacağına yönelik açıklamaları incelendiğinde, öğretmen adaylarının \%6,90'ının doğru açıklama kategorisinde cevap verdikleri görülmektedir (Tablo 3). Öğretmen adaylarının \%62,07'sinin verdikleri cevaplar kısmen doğru açıklama kategorisinde yer almaktadır. Öğretmen adaylarının cevaplarının \%24,14'ü yanlış açıklama kategorisindedir. Açıklama yapmayan öğretmen adaylarının oranı \%6,90'dur. Öğretmen adayları görüntü oluşumu için, en az iki ışın kullanılmas1 ile (Ö1, Ö4, Ö6, Ö11, Ö20), yansıma kanunlarının uygulanmas1 ile (Ö4, Ö6, Ö11) ve cismin simetrik yansımasının alınması ile (Ö14, Ö16, Ö17) çizim yapıldığını belirtmiştir. Ayrıca öğretmen adaylarının 16'sının (Ö2, Ö3, Ö5, Ö7, Ö8, Ö11, Ö13, Ö14, Ö15, Ö16, Ö17, Ö18, Ö21, Ö22, Ö23, Ö29) örnek görüntü çizimi yaptığ1 ve çizimlerinde çoğunlukla düzlem aynanın kullanıldığ1 görülmüştür. Öğretmen adaylarının görüntü çizimlerine ve çizimlere ilişkin açıklamalarına yönelik örnekler Şekil 1'de verilmiştir.

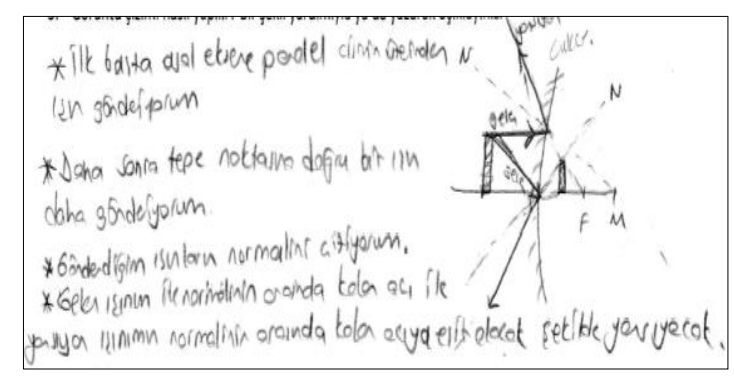

(a). Ö11 kodlu öğretmen adayının görüntü çizimi

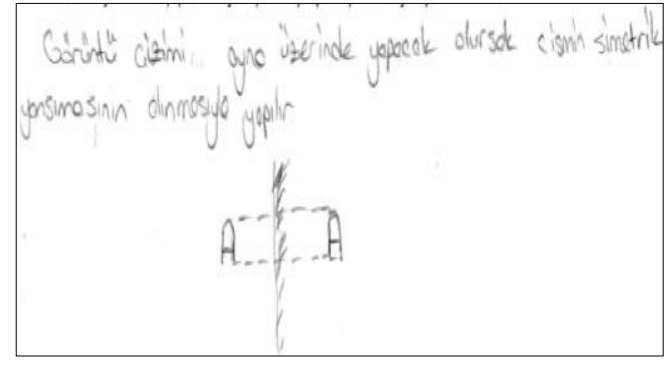

(b). Ö14 kodlu öğretmen adayının görüntü çizimi 


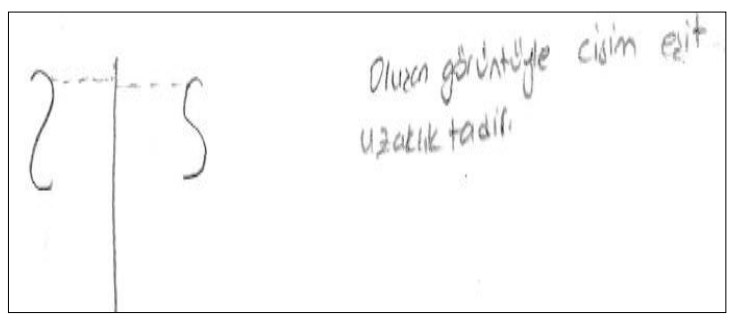

(c). Ö16 kodlu öğretmen adayının görüntü çizimi

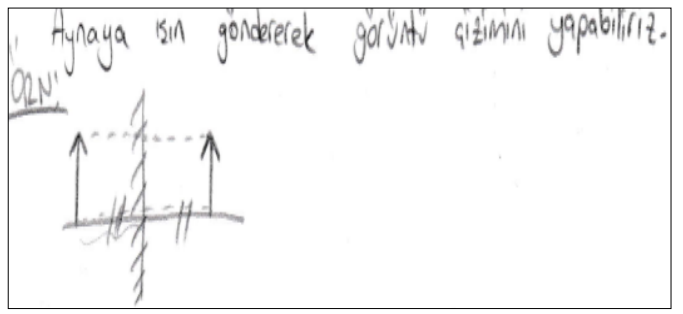

(d). Ö22 kodlu öğretmen adayının görüntü çizimi

Şekil 1. Öğretmen adaylarının görüntü çizimi örnekleri

Öğretmen adaylarının düzlem aynada görüntü çizimlerinin ve yaptıkları çizimlere ilişkin açıklamalarının kategorilere göre dağglımı Tablo 4 'te verilmektedir.

Tablo 4.

Adayların düzlem aynada yaptıkları görüntü çizimleri ve çizimlere ilişkin açıklamaları

\begin{tabular}{|c|c|c|c|c|}
\hline Kategori & & Ö. Adayı & f & $\%$ \\
\hline \multirow{4}{*}{ 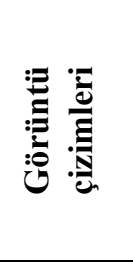 } & Doğru çizim & Ö5, Ö7, Ö24, Ö29 & 4 & 13,79 \\
\hline & $\begin{array}{l}\text { Kısmen doğru } \\
\text { çizim }\end{array}$ & $\begin{array}{l}\text { Ö1, Ö2, Ö3, Ö4, Ö8, Ö9, Ö10, Ö11, Ö12, Ö13, Ö14, } \\
\text { Ö15, Ö16, Ö17, Ö19, Ö20, Ö21, Ö22, Ö23, Ö27 }\end{array}$ & 20 & 68,97 \\
\hline & Yanlış çizim & Ö26, Ö28 & 2 & 6,90 \\
\hline & $\begin{array}{l}\text { Çizim } \\
\text { yapılmadı }\end{array}$ & Ö6, Ö18, Ö25 & 3 & 10,34 \\
\hline \multirow{4}{*}{ 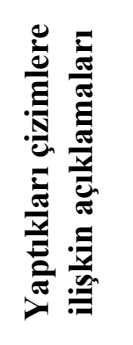 } & $\begin{array}{l}\text { Doğru } \\
\text { açıklama }\end{array}$ & $\begin{array}{l}\text { Ö1, Ö2, Ö4, Ö5, Ö7, Ö8, Ö10, Ö14, Ö16, Ö17, Ö20, } \\
\text { Ö21, Ö22, Ö24, Ö29 }\end{array}$ & 15 & 51,72 \\
\hline & $\begin{array}{l}\text { Kısmen doğru } \\
\text { açıklama }\end{array}$ & Ö3, Ö12, Ö19, Ö23, Ö26, Ö27, Ö28 & 7 & 24,14 \\
\hline & $\begin{array}{l}\text { Yanlış } \\
\text { açıklama }\end{array}$ & - & - & --- \\
\hline & $\begin{array}{l}\text { Açıklama } \\
\text { yapılmadi }\end{array}$ & Ö6, Ö9, Ö11, Ö13, Ö15, Ö18, Ö25 & 7 & 24,14 \\
\hline
\end{tabular}

* Aynalara gönderilen ışınlar yanlış ya da eksik çizilmesine rağmen, görüntünün aynaya olan uzaklığı, boyu ve görüntünün durumu (ters ya da düz oluşu) doğru çizildiyse, öğretmen adaylarının görüntü çizimleri kısmen doğru cevap kategorisinde değerlendirilmiştir.

Öğretmen adaylarının düzlem aynada görüntü çizimlerinin \%13,79'unun doğru, \%68,97'sinin kısmen doğru ve \%6,90'ının yanlış çizim kategorilerinde bulunduğu görülmektedir (Tablo 4). Adayların \%10,34'ü çizim yapmamıştır. Adayların yaptıkları çizimlere ilişkin açıklamalarının $\% 51,72$ 'si doğru ve \%24,14'ü kısmen doğru açıklama kategorilerinde yer almaktadır. Öğretmen adaylarının yanlış çizim yapmalarına rağmen, yanlış açıklama kategorisinde bulunan cevaplar vermedikleri görülmektedir. Öğretmen adaylarının \%14,14'ü ise yaptıkları çizimlere yönelik açıklama yapmamıştır. Öğretmen adaylarının verilen bir cismin düzlem aynadaki görüntü çizimine ve görüntüsünün özelliklerine yönelik açıklamaları bireysel olarak değerlendirilmiş ve değerlendirme sonuçları Tablo 5'te sunulmuştur.

Tablo 5.

Adayların düzlem aynada yaptıkları görüntü çizimleri ve çizimlere ilişkin açıklamalarının bireysel değerlendirilmesi

\begin{tabular}{|c|c|c|c|c|c|}
\hline & $\begin{array}{l}\text { Görüntü } \\
\text { çizimleri }\end{array}$ & $\begin{array}{l}\text { Yaptıkları çizimlere } \\
\text { ilişkin açıklamaları }\end{array}$ & Ö. Adayı & $\mathbf{f}$ & $\%$ \\
\hline \multirow{2}{*}{ 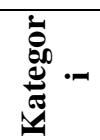 } & Doğru çizim & Doğru açıklama & Ö5, Ö7, Ö24, Ö29 & 4 & 13,79 \\
\hline & $\begin{array}{l}\text { Kısmen doğru } \\
\text { çizim }\end{array}$ & Doğru açıklama & $\begin{array}{l}\text { Ö1, Ö2, Ö4, Ö8, Ö10, Ö14, Ö16, } \\
\text { Ö17, Ö20, Ö21, Ö22 }\end{array}$ & 11 & 37,93 \\
\hline
\end{tabular}




\begin{tabular}{lllll}
\hline $\begin{array}{l}\text { Kısmen doğru } \\
\text { çizim }\end{array}$ & $\begin{array}{l}\text { Kısmen doğru } \\
\text { açıklama }\end{array}$ & Ö3, Ö12, Ö19, Ö23, Ö27 & 5 & 17,24 \\
\hline $\begin{array}{l}\text { Kısmen doğru } \\
\text { çizim }\end{array}$ & Açıklama yapılmadı & Ö9, Ö11, Ö13, Ö15 & 4 & 13,79 \\
\hline Yanlış çizim & $\begin{array}{l}\text { Kısmen doğru } \\
\text { açıklama }\end{array}$ & Ö26, Ö28 & 2 & 6,90 \\
\hline Çizim yapılmadı & Açıklama yapılmadı & Ö6, Ö18, Ö25 & 3 & 10,34 \\
\hline
\end{tabular}

Öğretmen adaylarının düzlem aynada yaptıkları görüntü çizimleri ve çizimlere ilişkin açıklamaları birlikte değerlendirildiğinde, öğretmen adaylarının \%13,79’unun hem doğru çizim hem de doğru açıklama yapabildikleri görülmektedir (Tablo 5). Öğretmen adaylarının \%37,93'ü kısmen doğru görüntü çizimi yaparken çizime ait doğru açıklamalar yaptıkları, \%17,24'ü ise kısmen doğru görüntü çizimi yaparken çizime ait kısmen doğru açıklamalar yaptıkları belirlenmiştir. Kısmen doğru çizim yapmalarına rağmen, çizime ait açıklama yapamayan öğretmen adaylarının oranı \%13,79'dur. Öğretmen adaylarının \%6,90'ı yanlış çizim yapmalarına rağmen çizime ait kısmen doğru açıklamalar yaptıkları tespit edilmiştir. Öğretmen adaylarının \%10,34'ü bu soruya cevap vermemiştir. Öğretmen adaylarının düzlem aynaya ait görüntü çizimleri ve çizimlerine ilişkin açıklamalarından bazıları Şekil 2'de verilmiştir.

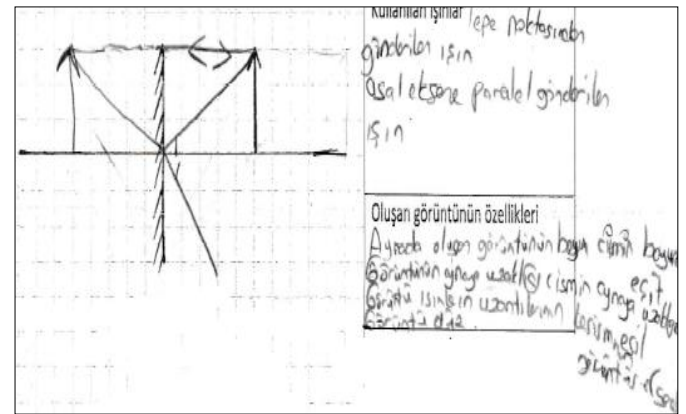

(a). Ö5 kodlu öğretmen adayı (doğru çizim-doğru açıklama)

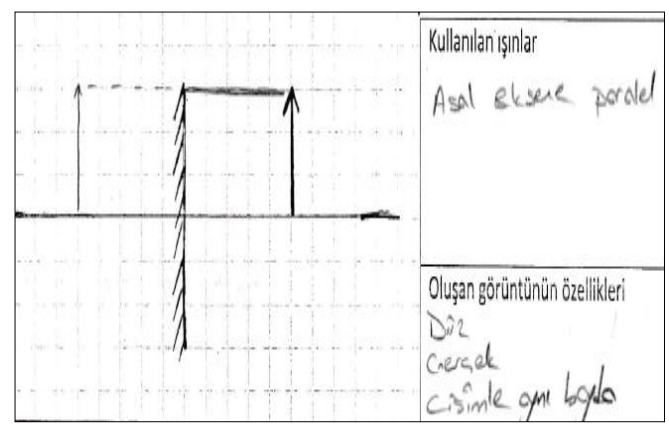

(c). Ö23 kodlu öğretmen aday1 (kısmen doğru çizim-kısmen doğru açıklama)

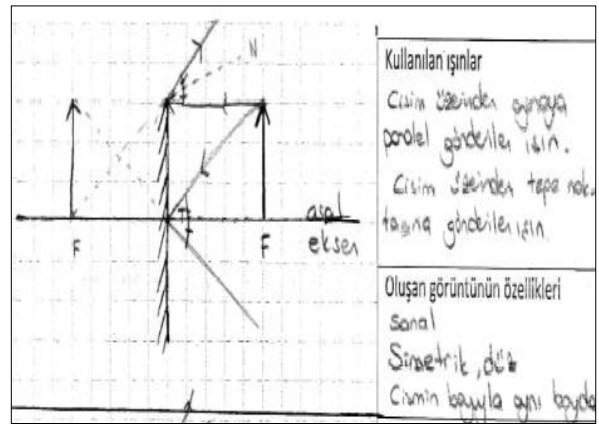

(b). Ö1 kodlu öğretmen adayı (kısmen doğru çizim-doğru açıklama)

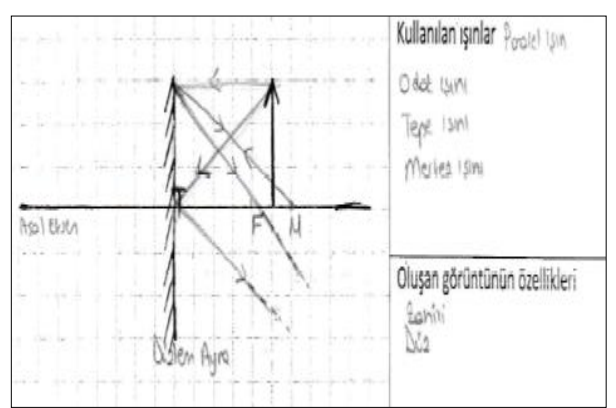

(d). Ö28 kodlu öğretmen adayı (yanlış çizim-kısmen doğru açıklama)

Şekil 2. Düzlem aynada görüntü çizimlerine ve görüntünün özelliklerine yönelik örnekler

Öğretmen adaylarının çukur aynada görüntü çizimlerinin ve yaptıkları çizimlere ilişkin açıklamalarının kategorilere göre dağılımı Tablo 6'da verilmektedir. 
Tablo 6.

Adayların çukur aynada yaptıkları görüntü çizimleri ve çizimlere ilişkin açıklamaları

\begin{tabular}{|c|c|c|c|c|}
\hline Kategori & & Ö. Adayı & f & $\%$ \\
\hline \multirow{4}{*}{ لِّ } & Doğru çizim & Ö3, Ö20 & 2 & 6,90 \\
\hline & Kısmen doğru çizim & Ö7, Ö10, Ö21, Ö22, Ö23 & 5 & 17,24 \\
\hline & Yanlış çizim & $\begin{array}{l}\text { Ö1, Ö2, Ö4, Ö5, Ö6, Ö8, Ö11, Ö13, Ö14, Ö16, } \\
\text { Ö17, Ö19, Ö24, Ö25, Ö26, Ö27, Ö28, Ö29 }\end{array}$ & 18 & 62,07 \\
\hline & Çizim yapılmadı & Ö9, Ö12, Ö15, Ö18 & 4 & 13,79 \\
\hline \multirow{4}{*}{ 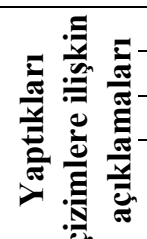 } & Doğru açıklama & Ö3, Ö7, Ö10, Ö20, Ö22, Ö23 & 6 & 20,69 \\
\hline & Kısmen doğru açıklama & Ö19, Ö21, Ö25, Ö26, Ö27, Ö28 & 6 & 20,69 \\
\hline & Yanlış açıklama & Ö2, Ö4, Ö5, Ö6, Ö8, Ö14, Ö16, Ö17, Ö29 & 9 & 31,03 \\
\hline & Açıklama yapılmadı & Ö1, Ö9, Ö11, Ö12, Ö13, Ö15, Ö18, Ö24 & 8 & 27,59 \\
\hline
\end{tabular}

* Aynalara gönderilen 1şınlar yanlış ya da eksik çizilmesine rağmen, görüntünün aynaya olan uzaklığı, boyu ve görüntünün durumu (ters ya da düz oluşu) doğru çizildiyse, öğretmen adaylarının görüntü çizimleri kısmen doğru cevap kategorisinde değerlendirilmiştir.

Öğretmen adaylarının çukur aynada görüntü çizimlerinin \%6,90'1nın doğru, \%17,24'ünün kısmen doğru ve \%62,07'sinin yanlış çizim kategorilerinde bulunduğu görülmektedir (Tablo 6). Adayların \%13,79'u çizim yapmamıştır. Adayların yaptıkları çizimlere ilişkin açıklamalarının \%20,69’u doğru, \%20,69'u kısmen doğru ve \%31,03'ü yanlış açıklama kategorilerinde yer almaktadır. Öğretmen adaylarının \%27,59'u ise yaptıkları çizimlere yönelik açıklama yapmamıştır. Öğretmen adaylarının verilen bir cismin çukur aynadaki görüntü çizimine ve görüntüsünün özelliklerine yönelik açıklamaları bireysel olarak değerlendirilmiş ve değerlendirme sonuçları Tablo 7'de sunulmuştur.

Tablo 7.

Adayların çukur aynada yaptıkları görüntü çizimleri ve çizimlere ilişkin açıklamalarının bireysel de ğerlendirilmesi

\begin{tabular}{|c|c|c|c|c|c|}
\hline & $\begin{array}{l}\text { Görüntü } \\
\text { çizimleri }\end{array}$ & $\begin{array}{l}\text { Yaptıkları çizimlere } \\
\text { ilişkin açılamaları }\end{array}$ & Ö. Adayı & f & $\%$ \\
\hline \multirow{7}{*}{ 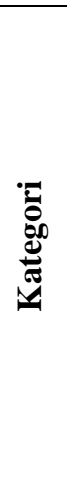 } & Doğru çizim & Doğru açıklama & Ö3, Ö20 & 2 & 6,90 \\
\hline & $\begin{array}{l}\text { Kısmen doğru } \\
\text { çizim }\end{array}$ & Doğru açıklama & Ö7, Ö10, Ö22, Ö23 & 4 & 13,79 \\
\hline & $\begin{array}{l}\text { Kısmen doğru } \\
\text { çizim }\end{array}$ & $\begin{array}{l}\text { Kismen doğru } \\
\text { açıklama }\end{array}$ & Ö21 & 1 & 3,45 \\
\hline & Yanlış çizim & $\begin{array}{l}\text { Kısmen doğru } \\
\text { açıklama }\end{array}$ & Ö19, Ö25, Ö26, Ö27, Ö28 & 5 & 17,24 \\
\hline & Yanlış çizim & Yanlış açıklama & $\begin{array}{l}\text { Ö2, Ö4, Ö5, Ö6, Ö8, Ö14, Ö16, Ö17, } \\
\text { Ö29 }\end{array}$ & 9 & 31,03 \\
\hline & Yanlış çizim & Açıklama yapılmadı & Ö1, Ö11, Ö13, Ö24 & 4 & 13,79 \\
\hline & Çizim yapılmadı & Açıklama yapılmadı & Ö9, Ö12, Ö15, Ö18 & 4 & 13,79 \\
\hline
\end{tabular}

Öğretmen adaylarının çukur aynada yapılan görüntü çizimleri ve çizimlere ilişkin açıklamaları birlikte değerlendirildiğinde, öğretmen adaylarının \%6,90'ının hem doğru çizim hem de doğru açıklama yapabildikleri görülmektedir (Tablo 7). Öğretmen adaylarının \%13,79'u kısmen doğru görüntü çizimi yaparken çizime ait doğru açıklamalar yaptıkları belirlenmiştir. Adayların \%3,45'i kısmen doğru görüntü çizimi ve bu çizime ait kısmen doğru açıklamalar yapmıştır. Bununla birlikte, öğretmen adaylarının \%17,24'ü yanlış çizim yapmalarına rağmen çizime ait kısmen doğru açıklamalar yaptıkları tespit edilmiştir. Öğretmen adaylarının \%31,03'ü çukur aynada görüntü çizimini ve görüntüye ait açıklamaları yanlış yaptıkları görülmektedir. Adayların \%13,79’u bu soruya cevap vermemiştir. 
Öğretmen adaylarının çukur aynaya ait görüntü çizimleri ve çizimlerine ilişkin açıklamalarından bazıları Şekil 3’te verilmiştir.

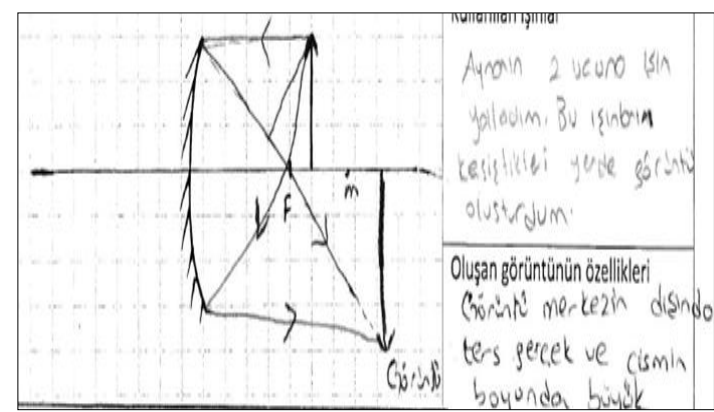

(a). Ö20 kodlu öğretmen adayı

(doğru çizim-doğru açıklama)

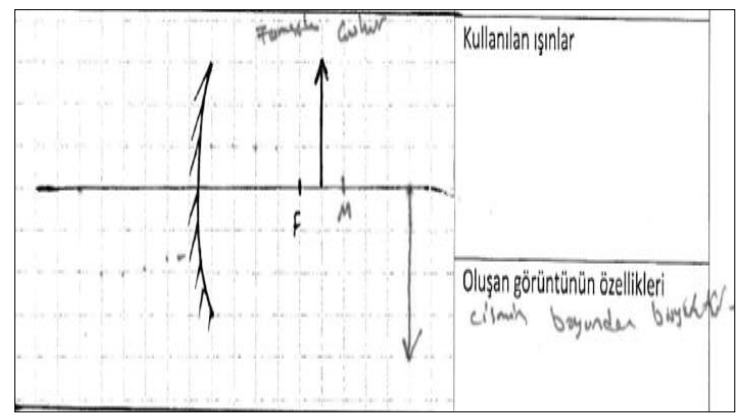

(c). Ö21 kodlu öğretmen aday1

(kısmen doğru çizim-kısmen doğru açıklama)

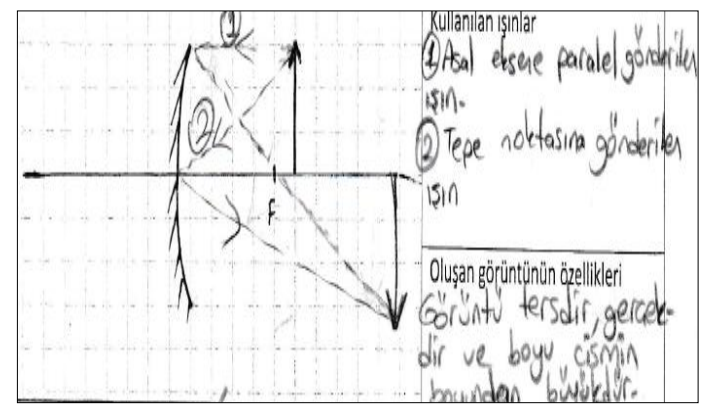

(b). Ö22 kodlu öğretmen aday1

(kısmen doğru çizim-doğru açıklama)

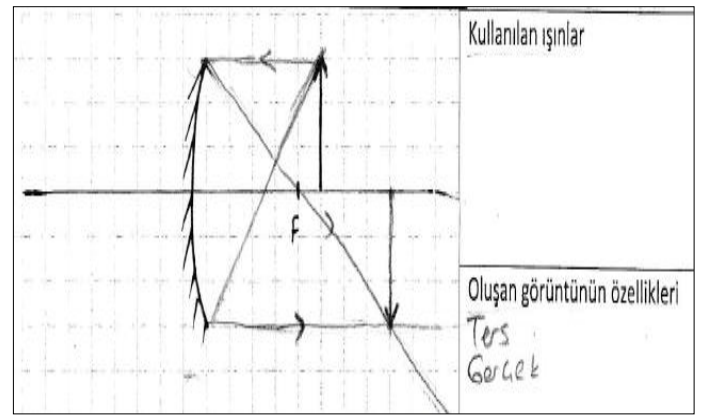

(d). Ö19 kodlu öğretmen adayı

(yanlış çizim-kısmen doğru açıklama)

Şekil 3. Çukur aynada görüntü çizimlerine ve görüntünün özelliklerine yönelik örnekler

Öğretmen adaylarının tümsek aynada görüntü çizimlerinin ve yaptıkları çizimlere ilişkin açıklamalarının kategorilere göre dağılımı Tablo 8'de verilmektedir.

Tablo 8.

Adayların tümsek aynada yaptıkları görüntü çizimleri ve çizimlere ilişkin açıklamaları

\begin{tabular}{|c|c|c|c|c|}
\hline Kategori & & Ö. Adayı & f & $\%$ \\
\hline \multirow{4}{*}{ لِّ } & Doğru çizim & Ö2, Ö4, Ö11, Ö12, Ö22, Ö24 & 6 & 20,69 \\
\hline & Kısmen doğru çizim & Ö14, Ö20, Ö21, Ö23 & 4 & 13,79 \\
\hline & Yanlış çizim & $\begin{array}{l}\text { Ö1, Ö3, Ö6, Ö7, Ö8, Ö9, Ö10, Ö13, Ö25, } \\
\text { Ö27, Ö28, Ö29 }\end{array}$ & 12 & 41,38 \\
\hline & Çizim yapılmadı & Ö5, Ö15, Ö16, Ö17, Ö18, Ö19, Ö26 & 7 & 24,14 \\
\hline \multirow{4}{*}{ 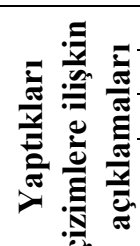 } & Doğru açıklama & Ö2, Ö4, Ö14, Ö22, Ö24 & 5 & 17,24 \\
\hline & Kısmen doğru açıklama & Ö8, Ö12, Ö16, Ö20, Ö21, Ö23, Ö28 & 7 & 24,14 \\
\hline & Yanlış açıklama & Ö3, Ö7, Ö10 & 3 & 10,34 \\
\hline & Açıklama yapılmadı & $\begin{array}{l}\text { Ö1, Ö5, Ö6, Ö9, Ö11, Ö13, Ö15, Ö17, Ö18, } \\
\text { Ö19, Ö25, Ö26, Ö27, Ö29 }\end{array}$ & 14 & 48,28 \\
\hline
\end{tabular}

* Aynalara gönderilen ışınlar yanlış ya da eksik çizilmesine rağmen, görüntünün aynaya olan uzaklığı, boyu ve görüntünün durumu (ters ya da düz oluşu) doğru çizildiyse, öğretmen adaylarının görüntü çizimleri kısmen doğru cevap kategorisinde değerlendirilmiştir.

Öğretmen adaylarının tümsek aynada görüntü çizimlerinin \%20,69’unun doğru, \%13,79’unun kısmen doğru ve \%41,38'inin yanlış çizim kategorilerinde bulunduğu görülmektedir (Tablo 8). 
Adayların \%24,14'ü çizim yapmamıştır. Yaptıkları çizimlere ilişkin açıklamalarının \%17,24'ü doğru, $\% 24,14$ 'ü kısmen doğru ve \%10,34'ü yanlış açıklama kategorilerinde yer almaktadır. Öğretmen adaylarının \%48,28'i ise yaptıkları çizimlere yönelik açılama yapmamıştır. Öğretmen adaylarının verilen bir cismin tümsek aynadaki görüntü çizimine ve görüntüsünün özelliklerine yönelik açıklamaları bireysel olarak değerlendirilmiş ve değerlendirme sonuçları Tablo 9'da sunulmuştur.

Tablo 9.

Adayların tümsek aynada yaptıkları görüntü çizimleri ve çizimlere ilişkin açıklamalarının bireysel değerlendirilmesi

\begin{tabular}{|c|c|c|c|c|c|}
\hline & Görüntü çizimleri & $\begin{array}{l}\text { Yaptıkları çizimlere } \\
\text { ilişkin açılamaları }\end{array}$ & Ö. Adayı & f & $\%$ \\
\hline \multirow{10}{*}{ 苞 } & Doğru çizim & Doğru açıklama & Ö2, Ö4, Ö22, Ö24 & 4 & 13,79 \\
\hline & Doğru çizim & $\begin{array}{l}\text { Kısmen doğru } \\
\text { açıklama }\end{array}$ & Ö12 & 1 & 3,45 \\
\hline & Doğru çizim & Açıklama yapılmadı & Ö11 & 1 & 3,45 \\
\hline & Kısmen doğru çizim & Doğru açıklama & Ö14 & 1 & 3,45 \\
\hline & Kısmen doğru çizim & $\begin{array}{l}\text { Kısmen doğru } \\
\text { açıklama }\end{array}$ & Ö20, Ö21, Ö23 & 3 & 10,34 \\
\hline & Yanlış çizim & $\begin{array}{l}\text { Kısmen doğru } \\
\text { açıklama }\end{array}$ & Ö8, Ö28 & 2 & 6,90 \\
\hline & Yanlış çizim & Yanlış açılama & Ö3, Ö7, Ö10 & 3 & 10,34 \\
\hline & Yanlıș çizim & Açıklama yapılmadı & Ö1, Ö6, Ö9, Ö13, Ö25, Ö27, Ö29 & 7 & 24,14 \\
\hline & Çizim yapılmadi & $\begin{array}{l}\text { Kısmen doğru } \\
\text { açıklama }\end{array}$ & Ö16 & 1 & 3,45 \\
\hline & Çizim yapılmadı & Açıklama yapılmadı & Ö5, Ö15, Ö17, Ö18, Ö19, Ö26 & 6 & 20,69 \\
\hline
\end{tabular}

Öğretmen adaylarının tümsek aynada yapılan görüntü çizimleri ve çizimlere ilişkin açıklamaları birlikte değerlendirildiğinde, öğretmen adaylarının \%13,79'unun hem doğru çizim hem de doğru açıklama yapabildikleri görülmektedir (Tablo 9). Öğretmen adaylarının \%3,45'i kısmen doğru görüntü çizimi yaparken çizime ait doğru açıklamalar yaptıkları belirlenmiştir. Öğretmen adaylarının \%6,90'1 yanlış çizim yapmalarına rağmen çizime ait kısmen doğru açıklamalar yaptıkları tespit edilmiştir. Yine, öğretmen adaylarının \%3,45'i çizim yapmamalarına rağmen çizime ait kısmen doğru açıklamalar yaptıkları görülmektedir. Öğretmen adaylarının \%20,69'u bu soruya cevap vermemiştir. Öğretmen adaylarının tümsek aynaya ait görüntü çizimleri ve çizimlerine ilişkin açıklamalarından bazıları Şekil 4'te verilmiştir.

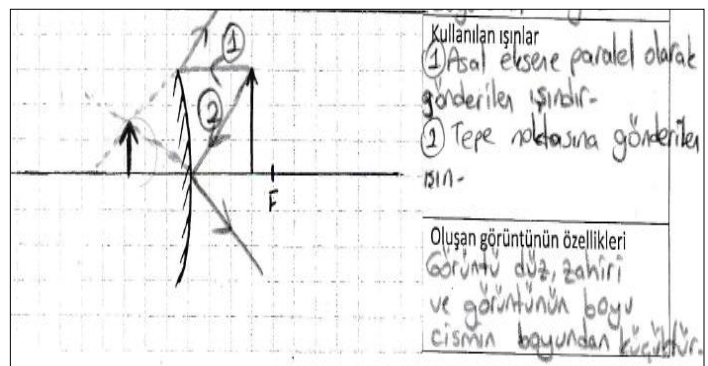

(a). Ö22 kodlu öğretmen adayı (doğru çizim-doğru açıklama)

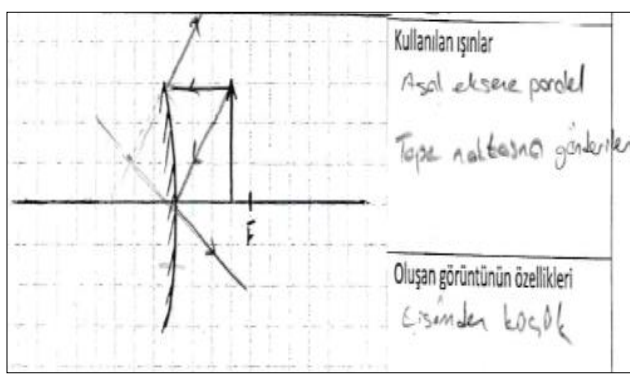

(b). Ö23 kodlu öğretmen adayı (kısmen doğru çizim-kısmen doğru açıklama) 


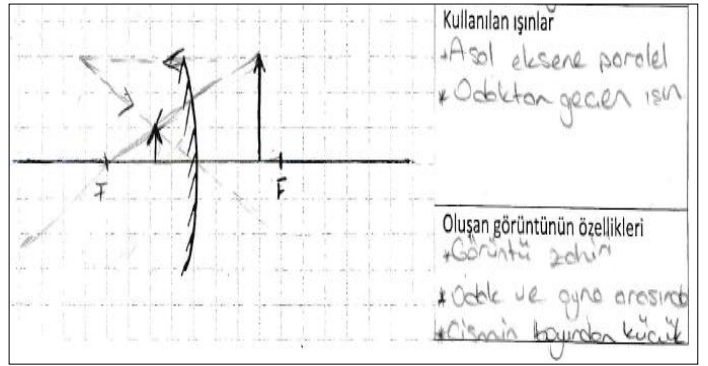

(c). Ö14 kodlu öğretmen adayı

(kısmen doğru çizim-doğru açıklama)

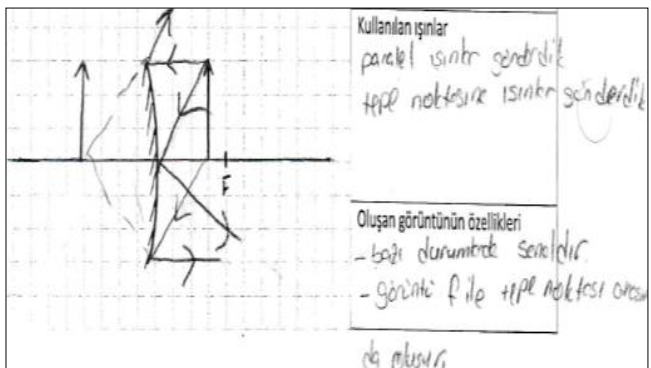

(d). Ö8 kodlu öğretmen aday1

(yanlış çizim-kısmen doğru açıklama)

Şekil 4. Tümsek aynada görüntü çizimlerine ve görüntünün özelliklerine yönelik örnekler

\subsection{Fen bilgisi öğretmen adaylarının aynalarda görüntü konusuna dair zihinsel modelleri}

Ek-2'de yer alan tablo ile birlikte, veriler bir bütün olarak değerlendirilerek adayların zihinsel modellerine ulaşılmış ve ulaşılan zihinsel modeller Tablo 10'da özetlenerek sunulmuştur.

Tablo 10.

Adayların aynalarda görüntü konusundaki sahip oldukları zihinsel modeller

\begin{tabular}{llll}
\hline Zihinsel Model Türü & Ö. Adayı & f & $\boldsymbol{\%}$ \\
\hline TİP1 & Ö20, Ö22 & 2 & 6,90 \\
\hline TİP2 & Ö2, Ö4, Ö7, Ö11, Ö14 & 5 & 17,24 \\
\hline TİP3 & Ö1, Ö6, Ö8, Ö18, Ö28 & 5 & 17,24 \\
\hline TİP4 & Ö3, Ö5, Ö10, Ö12, Ö21, Ö23, Ö29 & 7 & 24,14 \\
\hline TİP5 & Ö9, Ö16, Ö17, Ö25, Ö26, Ö27 & 6 & 20,69 \\
\hline TİP6 & Ö24 & 1 & 3,45 \\
\hline TİP7 & Ö13, Ö15, Ö19 & 3 & 10,34 \\
\hline
\end{tabular}

Öğretmen adaylarının aynalarda görüntü konusuna ait teorik ve pratik bloklardaki sorulara verilen yanıtları birlikte değerlendirildiğinde, adayların 7 farklı zihinsel modele sahip oldukları tespit edilmiştir (Tablo 10). Öğretmen adaylarının \%6,90'ı teorik ve pratik blokta yer alan sorulara doğru cevaplar verebildikleri TIP1 olarak adlandırılan zihinsel model tipine sahiptir. Adayların \%17,24’ü konuya yönelik teorik bloktaki sorulara doğru ve pratik bloktaki sorulara kısmen doğru cevaplar verdikleri TİP2 ve yine \%17, 24'ü konuya yönelik teorik bloktaki sorulara doğru ve pratik bloktaki sorulara yanlış cevaplar verdikleri TiP3 zihinsel modele sahip oldukları görülmektedir. Adayların önemli bir kısmı ise TIPP4 (teorik ve pratik bloktaki sorulara kısmen doğru cevaplar verdikleri) ve TİP5 (teorik bloktaki sorulara kısmen doğru ve pratik bloktaki sorulara yanlış cevaplar verdikleri) olarak isimlendirilen zihinsel modellere sahiptir. Bir aday ise konuya dair teorik bloktaki sorulara ait cevapları yanlış kategorisinde olmasına rağmen, pratik bloktaki sorulara ait cevapları doğru kategorisinde bulunan TİP6 türündeki zihinsel modele sahiptir. Adayların \%10,34'ü konuya yönelik teorik ve pratik blokta yer alan bütün sorulara yanlış cevap verdikleri TIP7 model türüne sahip oldukları belirlenmiştir.

\section{TARTIŞMA, SONUÇ ve ÖNERILER}

Fen bilgisi öğretmen adaylarının aynalarda görüntü konularındaki kavramsal anlamalarını ve zihinsel modellerini tespit etmeyi amaçlayan bu çalışmanın sonucunda öğretmen adaylarının görüntü ve özellikleri ile ilgili bilgi eksikliklerinin olduğu belirlenmiştir. Bu çalışma ile, öğretmen adaylarının görüntü ve görüntü oluşumunu açıklayamamalarının yanı sıra, görüntü çizimini yapamadıkları da ortaya çıkarılmıştır. Durukan ve Aygün (2014) çalışmasında öğretmen adaylarının görüntü çizimine dair bilimsel bilgilerle uyumlu çizimler yapamadıkları belirlenmiştir. Anıl ve Küçüközer (2010) çalışmasında lise öğrencilerinin "gözlemcinin konumu ile görüntü ilişkisi”, "düzlem aynada görüntünün 
yeri”, "cisim ile görüntü arasındaki ilişki" ve "görüntünün sahip olduğu özellikler" konularında alternatif kavramlara sahip olduğunu belirlemiştir.

Öğretmen adaylarının görüntü kavramını tanımlamaya yönelik yaptıkları açıklamaların önemli bir kısmı doğru cevap içermektedir. Görüntü kavramına yönelik yapılan açıklamalarda, adayların görüntü kavramını görüntü oluşumu, aynalar/yansıtıcı yüzeyi olan cisimler kullanılarak oluşturulan şekil, yansıma olayı veya gölge oluşumu ile açıkladıkları tespit edilmiştir. Kocakülah (2006) ile Çökelez ve Çiftçi-Yaşar (2015) çalışmalarında öğrencilerin görüntü oluşumunu görme olayı ile ilişkilendirdikleri, aynalarla bağlantılandırdıkları ve bazı öğrencilerinde görüntü oluşumunu çizimle açıkladıklarını tespit etmiştir. Kocakülah ve Demirci (2010) ise aynı zamanda öğrencilerin görüntü kavramıyla gölge ve aydınlanma kavramlarının birbirine karıştırıldı̆̆ını belirlemiştir.

Öğretmen adaylarının görüntünün oluşması için, en az iki ışın kullanılarak ışınların kendilerinin ya da uzantılarının kesiştirilmesi, yansıma kanunlarından yararlanılması veya cismin simetrik yansımasının alınması ile çizim yapıldığını belirttikleri ve örnek çizimler yaptıkları görülmüştür. Öğretmen adaylarının bir kısmı görüntü çizimini doğru yapabilmiştir. Adayların yanlış görüntü çizimlerinin genellikle, cisimden gönderilen ışınların hatalı olmasından veya eksik ışın kullanımından kaynaklanan hatalar sebebiyle olduğu görülmüştür. Çökelez ve Çiftçi-Yaşar (2015) öğrencilerin büyük bir kısmının görüntü oluşumunu görme olayı ve düzlem ayna kullanarak açıkladıklarını belirlemiştir. Ahçı (2012)'nin çalışmasında da öğrencilerin çok az bir kısmı görüntü çizimini doğru yapabilmiştir. Kocakülah (2006) ise çalışmasında 1şınları hatalı kullanımı sebebiyle görüntü çizimlerinin yanlış olduğundan bahsetmektedir. Durukan ve Aygün (2014) çalışmasında da benzer şekilde yanlış görüntü çizimlerinin optik aletlerin yanlış kullanımından veya cisimden gönderilen 1şınların hatalı olmasından kaynaklandığını tespit etmiştir.

Çalışmada öğretmen adaylarının farklı ayna türlerinde örnek görüntü çizimi yapmakta zorlandıkları ve görüntü çizimini doğru yapamadıkları için oluşan görüntünün özelliklerini belirtemedikleri tespit edilmiştir. Öğretmen adaylarının düzlem aynada görüntü çizimini küresel aynalara oranla kısmen de olsa doğru yaptıkları Tablo 3'te görülmektedir. Öğretmen adayları genellikle, düzlem aynaya gönderdikleri ışınları eksik çizmesine rağmen, görüntünün aynaya olan uzaklığını, boyunu ve görüntünün durumunu doğru çizdiği görülmüştür. Kocakülah (2006) ise ögrencilerin düzlem aynada oluşan görüntünün yerini "aynanın üzerinde veya içinde" şeklinde açıkladıklarını belirtmektedir. Anıl ve Küçüközer (2010) ise öğrencilerin "düzlem aynada görüntünün yeri”, "düzlem aynada cisim ile görüntü arasındaki ilişki”, "düzlem aynada görüntünün sahip olduğu özellikler”, "gözlemcinin konumu ile görüntü ilişkisi" ve "görüş alanının bağlı olduğu faktörler" konularında alternatif kavramlara sahip olduklarını belirlemiştir. Çalışma kapsamında öğretmen adaylarının çoğunlukla tümsek ve çukur aynada görüntü çizimlerini yanlış yaptığı görülmüştür. Benzer şekilde, Kara ve diğ. (2003) çalışmasında öğrencilerin çukur ve tümsek ayna ile ilgili bilgilerini kullanamadıklarını tespit etmiştir. Ayrıca bazı öğretmen adaylarının görüntü çizimini doğru bir şekilde yapamadıkları halde oluşan görüntünün özelliklerini doğru açıkladıkları görülmüştür. Bu durum, öğretmen adaylarının bazı bilgileri ezberleyerek edindiklerinin göstergesi olabilir. Benzer bir sonuca Durukan ve Aygün (2014) çalışmasında da ulaşmıştır.

Öğretmen adaylarının oldukça az bir kısmı (\%6,90’1) literatürde bilimsel model (Vosniadou \& Brewer, 1992), ideal model (İyibil, 2010) olarak adlandırılan ve bilimsel içerik barındıran TİP1 model türüne sahip oldukları görülmektedir. Yine, adayların az bir kısmının (\%10,34'ü) literatürde ilkel model (Vosniadou \& Brewer, 1992, 1994), uyumsuz model (İyibil, 2010) gibi adlandırılan ve bilimsel olmayan içerik barındıran TİP7 model türüne sahip oldukları görülmektedir. Bu çalışma kapsamında ortaya çıkarılan diğer zihinsel model türleri ise, literatürde sentez/hibrit model (Vosniadou \& Brewer, 1992, 1994; Franco \& Colinvaux, 2000) olarak adlandırılan ve içeriğinde hem bilimsel hem de bilimsel olmayan bilgi unsurları barındıran TİP2, TIP3, TİP4, TİP5 ve Tİ 6 zihinsel model türleridir. Bu çalışma kapsamında ortaya çıkan TÏP6 olarak isimlendirilen zihinsel model, kavrama dair bilginin yapılandırılarak içselleştirilmediğini ve bilginin yalnızca ezberlenerek verilen soruların çözümüne odaklanıldığının bir göstergesi olabilir.

Çalışmada, ulaşılan sonuçlar dikkate alınarak görüntü kavramı, görüntü oluşumu ve aynalarda görüntü konularının öğretimine yönelik olarak; öğretmen adaylarının fizik laboratuvarlarında özellikle görüntü çizimine yönlendirilmesi önerilmektedir. Öğrencilerin deney sırasında buldukları görüntünün 
yerini ve özelliklerini çizim yaparak doğrulamaları sağlanabilir. Laboratuvar derslerinde optik konuları ile ilgili farklı yöntem ve tekniklerle zenginleştirilmiş simülasyon kullanımı gibi görsel olarak desteklenmiş bir organizasyon ile işlenmesinin öğrencilerin kavramsal anlamalarını sağlamakta etkili olacağı düşünülmektedir.

\section{KAYNAKÇA}

Ahçı, M. (2012). Üniversite ögrencilerinin ışık ve optik konuları ile ilgili kavramsal anlamaları. Yayımlanmamış Yüksek Lisans Tezi, Balıkesir Üniversitesi, Balıkesir.

Anıl, Ö., \& Küçüközer, H. (2010). Ortaöğretim 9. sınıf öğrencilerinin düzlem ayna konusunda sahip oldukları ön bilgi ve kavram yanılgılarının belirlenmesi. Türk Fen Eğitimi Dergisi, 7(3), 104-122.

Buckley, B. C., \& Boulter, C. J. (2000). Investigating the role of representations and expressed models in building mental models. In J. K. Gilbert, \& C. J. Boulter (Eds.), Developing models in science education (pp. 119135). New York: Springer.

Chi, M.T.H. (1992). Conceptual change within and across ontological categories: Examples from learning and discovery in science. R. Giere (Ed.), Cognitive models of science: Minnesota studies in the philosophy of science (s.129-186). Minneapolis: University of Minnesota Press.

Çepni, S. (2010). Araştırma ve proje çalışmalarına giriş (5. baskı). Trabzon: Celepler Matbaacıllk.

Çiftçi, S., \& Çökelez, A. (2012, Haziran). İlköğretim 6. sınıf öğrencilerinin 'görüntü kavramı' ile ilgili kavramsal ögrenmelerinin incelenmesi. X. Ulusal Fen Bilimleri ve Matematik Eğitimi Kongresi. Niğde Üniversitesi, Niğde.

Çökelez, A., \& Çiftçi-Yaşar, S. (2015). 6. sınıf öğrencilerinin 'görüntü kavramı' ile ilgili kavramsal öğrenmelerinin incelenmesi. Electronic Turkish Studies, 10(14), 159-180.

Durukan, Ü.G., \& Aygün, M. (2014, Ekim). Fen bilgisi öğretmen adaylarının görüntü çizimi ve görüntünün özellikleri hakkındaki bilgilerinin belirlenmesi. 9. Uluslararası Balkan Eğitim ve Bilim Kongresi. Trakya Üniversitesi, Edirne.

Franco, C., \& Colinvaux, D. (2000). Grasping mental models. In J. K. Gilbert, \& C. J. Boulter (Eds.), Developing models in science education (pp. 93-118). New York: Springer.

Galili, I., \& Hazan, A. (2000). Learners' knowledge in optics: Interpretation, structure and analysis. International Journal of Science Education, 22(1), 57-88.

Goldberg, F.M., \& McDermott, L.C. (1987). An investigation of student understanding of the real image formed by a coverging lens or concave mirror. American Journal of Physics, 55(2), 108-119.

Greca, I.M., \& Moreira, M. A. (2000). Mental models, conceptual models, and modelling. International Journal of Science Education, 22(1), 1-11.

Greca, I.M., \& Moreira, M. A. (2002). Mental, physical, and mathematical models in the teaching and learning of physics. Science Education, 86(1), 106-121.

Harrison, A.G., \& Treagust, D. F. (2000). A typology of school science models. International Journal of Science Education, 22(9), 1011-1026.

Hrepic, Z. (2002). Identifying students' mental models of sound propagation. Doctoral dissertation, Kansas State University, USA.

Hubber, P. (2006). Year 12 students' mental models of the nature of light. Research in Science Education, 36(4), 419-439.

İyibil, Ü.G. (2010). Farklı programlarda ögrenim gören öğretmen adaylarının temel astronomi kavramların anlama düzeylerinin ve ilgili kavramlara ait zihinsel modellerinin analizi. Yayımlanmamış Yüksek Lisans Tezi, Karadeniz Teknik Üniversitesi, Trabzon. 
İyibil, Ü.G., \& Sağlam-Arslan, A. (2010). Fizik öğretmen adaylarının yıldız kavramına dair zihinsel modelleri. Necatibey Ĕgitim Fakültesi Elektronik Fen ve Matematik Eğitimi Dergisi, 4(2), 25-46.

Kara, M., Kanlı U., \& Yağbasan, R. (2003). Lise 3. sınıf öğrencilerinin ışık ve optik ile ilgili anlamakta güçlük çektikleri kavramların tespiti ve sebepleri. Milli Eğitim Dergisi, 158, 221-232.

Kocakülah, A., \& Demirci, N. (2010). Ortaöğretim öğrencilerinin görüntü ve düzlem aynada görüntü oluşumuna ilişkin kavramsal anlamaları. Necatibey Eğitim Fakültesi Elektronik Fen ve Matematik Eğitimi Dergisi, 4(1), 141-162.

Kocakülah, A. (2006). İlköğretim 5. sınıf öğrencilerinin görüntü kavramı ve düzlem aynada görüntü oluşumu ile ilgili kavramsal anlamaları. Gazi Üniversitesi Kırşehir Eğitim Fakültesi, 7(1), 157-173.

Kurnaz, M.A., \& Değermenci, A. (2012). 7. sınıf öğrencilerinin güneş, dünya ve ay ile ilgili zihinsel modelleri. İlköğretim Online, 11(1), 137-150.

Miles, M. B., \& Huberman, A. M. (1994). Qualitative data analysis: An expanded sourcebook (2nd edition). Thousand Oaks: Sage Publications.

Norman, D. A. (1983). Some observations on mental models. In D. Gentner and A. Stevens (Eds.), Mental models (pp. 7-14). Hillsdale, NJ: Lawrence Erlbaum Associates.

Ornek, F. (2008). Models in science education: Applications of models in learning and teaching science. International Journal of Environmental and Science Education, 3(2), 35-45.

Patton, M. Q. (1990). Qualitative evaluation and research methods (2nd edition). Thousand Oaks: Sage Publications.

Şen, İ.A. (2003). İlköğretim öğrencilerinin 1şık, görme ve aynalar konusundaki kavram yanılgılarının ve öğrenme zorluklarının incelenmesi. Hacettepe Üniversitesi Eğitim Fakültesi Dergisi, 25, 176-185.

Ünal, G., \& Ergin, Ö. (2006). Fen eğitimi ve modeller. Milli Ĕgitim Dergisi, 171, 188-196.

Ünal-Çoban, G., \& Kaya-Şengören, S. (2009). Prospective physics teachers' mental models about shadow. Dokuz Eylül Üniversitesi Buca Eğitim Fakültesi Dergisi, 25, 1-8.

Vosniadou, S., \& Brewer, W. F. (1992). Mental models of the earth: A study of conceptual change in childhood. Cognitive psychology, 24(4), 535-585.

Vosniadou, S., \& Brewer, W. F. (1994). Mental models of the day/night cycle. Cognitive science, 18(1), 123-183.

Yin, R. K. (2003). Case study research and applications: Design and methods (3rd edition). Thousand Oaks: Sage publications. 


\section{Ek-1: Veri toplama aracı}

1. Görüntü denilince aklınıza ne geliyor? Açıklayınız. Açıklamanızı çizimlerle destekleyebilirsiniz.

2. Görüntü çizimi nasıl yapılır? Açıklayınız. Açıklamanızı çizimlerle destekleyebilirsiniz.

3. Aşağıda verilen cisimler için görüntü çizimlerini yapınız.

a. Görüntü çizimlerinizde kullandığınız ışınları belirtiniz.

b. Görüntünün özelliklerini belirtiniz.

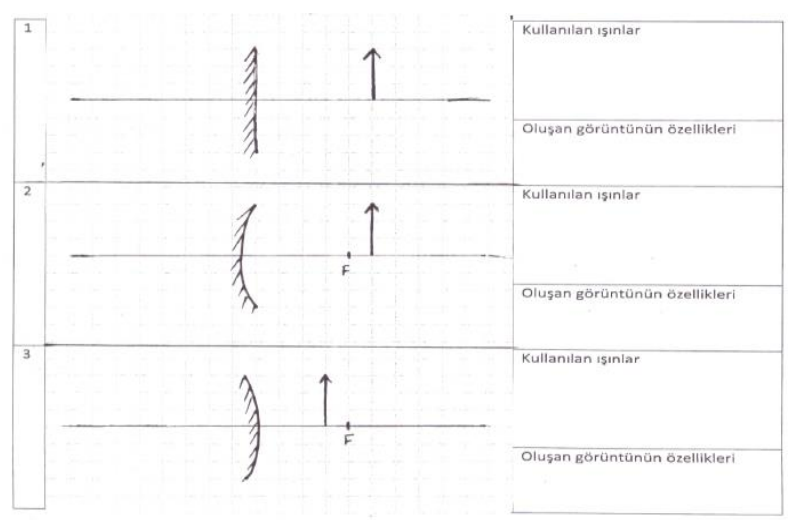

Ek-2: Adayların aynalarda görüntü konusundaki kavramsal anlamalarının değerlendirilmesi

\begin{tabular}{|c|c|c|c|c|c|c|c|c|c|c|c|c|c|c|c|}
\hline & \multicolumn{6}{|c|}{ Teorik blok } & \multicolumn{9}{|c|}{ Pratik blok } \\
\hline & \multicolumn{3}{|c|}{ 1.soru/Tablo1 } & \multicolumn{3}{|c|}{ 2.soru/Tablo2 } & \multicolumn{3}{|c|}{ 3.soru/Tablo3 } & \multicolumn{3}{|c|}{ 3.soru/Tablo5 } & \multicolumn{3}{|c|}{ 3.soru/Tablo7 } \\
\hline & $\mathrm{D}$ & KD & Y/B & $\mathrm{D}$ & KD & $\mathrm{Y} / \mathrm{B}$ & $\mathrm{D}$ & $\mathrm{KD}$ & $\mathrm{Y} / \mathrm{B}$ & $\mathrm{D}$ & $\mathrm{KD}$ & Y/B & $\mathrm{D}$ & $\mathrm{KD}$ & $\mathrm{Y} / \mathrm{B}$ \\
\hline Ö1 & $\checkmark$ & & & $\checkmark$ & & & & $\checkmark$ & & & & $\checkmark$ & & & $\checkmark$ \\
\hline Ö2 & $\checkmark$ & & & & $\checkmark$ & & & $\checkmark$ & & & & $\checkmark$ & $\checkmark$ & & \\
\hline Ö3 & & $\checkmark$ & & & & $\checkmark$ & & $\checkmark$ & & $\checkmark$ & & & & & $\checkmark$ \\
\hline Ö4 & $\checkmark$ & & & & $\checkmark$ & & & $\checkmark$ & & & & $\checkmark$ & $\checkmark$ & & \\
\hline Ö5 & & & $\checkmark$ & & $\checkmark$ & & $\checkmark$ & & & & & $\checkmark$ & & & $\checkmark$ \\
\hline Ö6 & $\checkmark$ & & & & $\checkmark$ & & & & $\checkmark$ & & & $\checkmark$ & & & $\checkmark$ \\
\hline Ö7 & $\checkmark$ & & & & $\checkmark$ & & $\checkmark$ & & & & $\checkmark$ & & & & $\checkmark$ \\
\hline Ö8 & $\checkmark$ & & & & $\checkmark$ & & & $\checkmark$ & & & & $r$ & & & $\checkmark$ \\
\hline Ö9 & & $\checkmark$ & & & & $\checkmark$ & & $\checkmark$ & & & & $\checkmark$ & & & $\checkmark$ \\
\hline Ö10 & . & $\checkmark$ & & & & $\checkmark$ & & $\checkmark$ & & & $\checkmark$ & & & & $\checkmark$ \\
\hline Ö11 & $\checkmark$ & & & & $\checkmark$ & & & $\checkmark$ & & & & $\checkmark$ & $\checkmark$ & & \\
\hline Ö12 & $\checkmark$ & & & & & $\checkmark$ & & $\checkmark$ & & & & $\checkmark$ & $\checkmark$ & & \\
\hline Ö13 & & & $\checkmark$ & & & $\checkmark$ & & $\checkmark$ & & & & $\checkmark$ & & & $r$ \\
\hline Ö14 & $\checkmark$ & & & & $\checkmark$ & & & $\checkmark$ & & & & $\checkmark$ & & $\checkmark$ & \\
\hline Ö15 & & & $\checkmark$ & & & $\checkmark$ & & $\checkmark$ & & & & $\checkmark$ & & & $\checkmark$ \\
\hline Ö16 & & & $\checkmark$ & & $\checkmark$ & & & $\checkmark$ & & & & $\checkmark$ & & & $\checkmark$ \\
\hline Ö17 & & & $\checkmark$ & & $\checkmark$ & & & $\checkmark$ & & & & $\checkmark$ & & & $\checkmark$ \\
\hline Ö18 & $\checkmark$ & & & & $\checkmark$ & & & & $\checkmark$ & & & $\checkmark$ & & & $\checkmark$ \\
\hline Ö19 & & & $\checkmark$ & & & $\checkmark$ & & $\checkmark$ & & & & $\checkmark$ & & & $\checkmark$ \\
\hline Ö20 & $\checkmark$ & & & $\checkmark$ & & & & $\checkmark$ & & $\checkmark$ & & & & $\checkmark$ & \\
\hline Ö21 & & 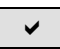 & & & $\checkmark$ & & & $\checkmark$ & & & $\checkmark$ & & & $\checkmark$ & \\
\hline Ö22 & $\checkmark$ & & & & $\checkmark$ & & & $\checkmark$ & & & $\checkmark$ & & $\checkmark$ & & \\
\hline Ö23 & & $\checkmark$ & & & $\checkmark$ & & & $\checkmark$ & & & $\checkmark$ & & & $\checkmark$ & \\
\hline Ö24 & & & $\checkmark$ & & & $\checkmark$ & $\checkmark$ & & & & & $r$ & $\checkmark$ & & \\
\hline Ö25 & & & $\checkmark$ & & $\checkmark$ & & & & $\checkmark$ & & & $\checkmark$ & & & $\checkmark$ \\
\hline Ö26 & & 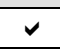 & & & $\checkmark$ & & & & $\checkmark$ & & & $\checkmark$ & & & $\checkmark$ \\
\hline Ö27 & & $\checkmark$ & & & & $\checkmark$ & & $\checkmark$ & & & & $\checkmark$ & & & $\checkmark$ \\
\hline Ö28 & $\checkmark$ & & & & $\checkmark$ & & & & $\checkmark$ & & & $\checkmark$ & & & $\checkmark$ \\
\hline Ö29 & & & $\checkmark$ & & $\checkmark$ & & $\checkmark$ & & & & & $\checkmark$ & & & $\checkmark$ \\
\hline
\end{tabular}

*Üçüncü soru için tabloya öğretmen adaylarının cevapları işlenirken, adayların görüntü çizimine dair cevapları esas alınmıştır. Bunun sebebi, görüntü çizimini yapamayan öğretmen adayının görüntünün özelliklerine yönelik açıklamalarının ezbere dayalı bilgi olduğu düşüncesidir. 